\title{
THE IMPACT OF IMPAIRMENT OF RECEIVABLES ON THE REALITY OF FINANCIAL REPORTING IN THE REPUBLIC OF SERBIA
}

\author{
Kosana Vićentijević^, Zoran Jović, Zoran Petrović \\ Singidunum University, Faculty of Business in Belgrade, 32 Danijelova Street, Belgrade, Serbia
}

\begin{abstract}
:
The paper discusses theoretical and practical aspects of calculating impairment of receivables in relation to the reality of financial reporting. The aim is to investigate the practice of calculating impaired receivables of the legal persons in the Republic of Serbia, with the aim to identify any failure (irregularities) that may affect the quality of financial reporting.

Many business entities have a large number of individual small buyers. The research herein conducted reveals that very few legal persons who determine impairment of receivables claim in the proper way, by treating a large number of individual small buyers as one portfolio. In this sense, we believe that the content of the paper and conclusions arising from it would encourage accountants to change the way of calculating impairment of receivables.
\end{abstract}

\author{
Key words: \\ accounts receivable, \\ impairment, \\ portfolio, \\ financial statements.
}

\section{INTRODUCTION}

Accounts receivable represent an important part of working capital of business entities. According to the data published in "Annual bulletin of financial statements for 2014”(Serbian Business Registers Agency, 2015), participation of receivables in total assets of all business entities, that delivered statistical data for the year 2014 , is $14,6 \%$. This percentage is determined by utilization of data of receivables indicated in balance sheet of business entities. Taking into account that face value of receivables is not indicated in the balance sheet, but the expected amount of their recovery, realistic interest of receivables in total assets of business entities is higher than the previously mentioned percentage.

The most difficult part regarding measuring accounts receivable performance, is the estimation of its impairment, according to the balance sheet data. Financial assets (including the impairment) is impaired if it is indicated in the amount that is above its estimated value which is reversible. (Petrovic, 2012). The correct amount of impairment of accounts receivable is the postulate for realistic financial reporting: realistic indication of impaired expenses in profit account and the realistic value of account receivables in balance sheet.

This is the reason why the topic of this work is theoretical and practical aspects of account of impairment and the affect on reality of financial reporting.

The aim of this work is to investigate the practice of the impaired accounts receivable in business entities in Serbia, in order to determine possible gaps (irregularities) that affect the quality of financial reporting.
Numerous business entities have a large number of individually small buyers. Those are usually state enterprises that do business with the population.

In this work, we are trying to prove the following hypotheses:

H1 - accounting standard that is implemented in Serbia enables realistic account of impaired accounts receivable.

$\mathrm{H} 2$ - considerable number of business entities enforces prescribed accounting standard for the account of impaired receivable incorrectly, which leads to underestimation of indicated amount of account receivables, and

H3 - tax policy indirectly affects additional irregular valuation of account receivables.

\section{MANDATORY REQUIREMENTS IN REFERENCE TO ESTIMATION OF IMPAIRED ACCOUNTS RECEIVABLE}

We could apply the following techniques for impairment estimates:

- Distinctive impairment estimates of each impaired account receivables

- Collective impairment estimates of all account receivables, and

- Composite techniques of estimation: distinctive impairment estimates of valuable accounts receivables and collective impairment estimates of accounts receivable, which analyzed distinctively are not materially valuable, but numerous. 
In the following example we will show possible problems in the case where we only utilizes the technique of distinctive impairment estimates in order to estimate impairment of accounts receivable: if a business entity has 10000 buyers (which is common for utility enterprises), taking into account that you can have more than one account receivable, it would be impossible to apply distinct impairment estimation - it would mean that someone (accountant, or, for instance, legal office) would analyze each buyer individually. If we were to spend 10 minutes on each buyer, it would mean that we spent more than 200 working days for review of impairments of these accounts receivable. Moreover, it would be hard to guarantee the accuracy of estimation. Such estimation could be compared to the estimation of reservation of expenses in the warranty period: for instance, if a business entity produces and sells 10000 kitchen stoves, it is certain that some of them would break during the warranty period, but it is challenging to estimate whether a concrete stove would break.

Therefore, we analyzed the representation of the previously mentioned techniques (in that way we tested the first hypothesis) in accounting standards which is enforced in assembling of annual financial statements in Serbia. For the assemblance of regular annual financial statements in Serbia, three regulations that include directive for additional estimation of account receivables are used:

1. International Financial Reporting Standards (IFRS)

2. International Financial Reporting Standards for small and medium-sized entities (IFRS for SMEs), and

3. The Rulebook on the method of recognition, valuation and disclosures of items in the financial statements of micro and other legal entities ("Official Gazette RS" No.118/2013 and 95/2014), further in the text: The Rulebook for micro and other legal entities.

In previously mentioned regulation, the following techniques of evaluation of impaired accounts receivable are implemented:

1. In paragraph 64 of IAS 39 Financial Instruments: Recognition and Measurement, composite technique of evaluation of impaired accounts receivable is anticipated. Namely, it is anticipated that a business entity estimates, firstly, whether there exists objective proof of the impairment of accounts receivable, which is important, individually analyzed. If a business entity estimates that there is an objective proof of impairment for financial instrument, which is estimated distinctively, whether it is important or not, it includes that instrument in the group of financial instruments with similar character of credit risk and jointly estimates its impairment. Instruments that are estimated individually due to decrease of value and for which the loss of decreased value is accepted or it is accepted continually, are not included in joint evaluation of their impairment.

2. In paragraph 24 of Section 11 Basic financial instruments IFRS for SMEs, the same type of evaluation of impairment of account receivables is prescribed: the impairment of accounts receivable that are distinctively valuable is individually estimated, and the rest of account receivables could be jointly estimated;

3. In Article 17 of the Rulebook for micro and other legal entities, the possibility of joint estimation of impairment of accounts receivable, when distinctively ana- lyzed, are not materially important, is not prescribed. However, this is not forbidden by this rulebook, as the Articel 6, Paragraph 3, prescribes that, in case when for specific situation and transaction, specific principles rules are not prescribed by the clauses of this Rulebook, business entity can enforce criteria for recognition and valuation of assets, responsibilities, income, expenses and business results prescribed by IFRS for SMEs.

In order to test the third hypothesis, we analyzed the clauses of Article 16 Law on Corporate Income Tax. They can have negative indirect effects on the reality of account of impairment of account receivables. Namely, it is prescribed that in tax balance sheet, the expenses on the basis of impairment of account receivables are accepted, provided that minimum 60 days has passed from their realization or return. Therefore, this means that the estimation of impairment, for the purpose of taxation, is done by utilization of technique of distinctive estimation, and from the point of view of determination of expenses, which are included in tax balance sheet, it is not thoroughly analyzed whether the account receivables are impaired or not. As stated, the only criteria is that 60 days has passed from the deadline for its realization or return, even though, realistically, the account receivables might not be impaired.

\section{METHODOLOGY AND RESEARCH RESULTS}

For the sake of testing the second hypothesis, we conducted research in September and October, 2015. The basic method of gathering data was through anonymous questioners with different structure of questions (open and closed type). The questioners were given to accountants of legal entities. The poll was conducted in the following cities in Serbia: Belgrade, Novi Sad, Subotica, Šabac, Niš and Valjevo. The research sample included 123 legal entities (no.1). Five questioners were not included in the analysis of the results, because the questioners were not filled in correctly.

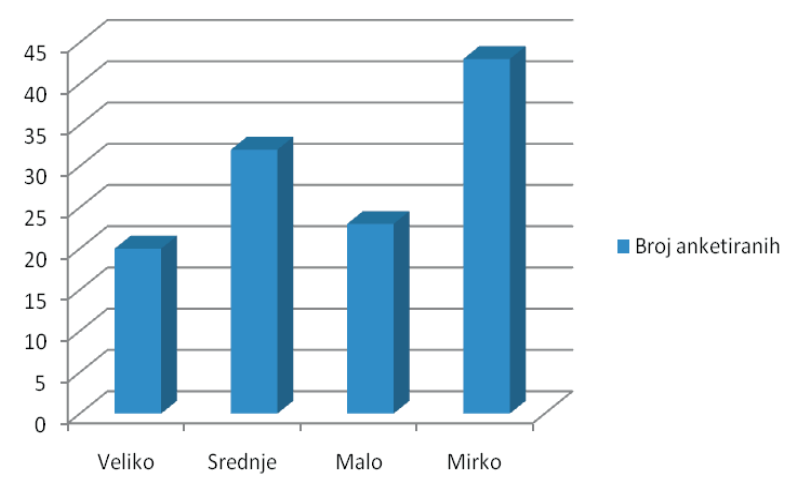

Image 1. The structure of examinee (legal entities) according to the Law on Accounting

The research results are indicated through the responses on some questions from the questioner and we analyzed them through the following comments and images:

1. How many days are anticipated to pass from the day of return of accounts receivable in our accounting policy, in order to do the impairment of accounts receivable indirectly? 
The research results (Image 2) indicate that 112 legal entities or $95 \%$ of the examinees responded: 60 days.

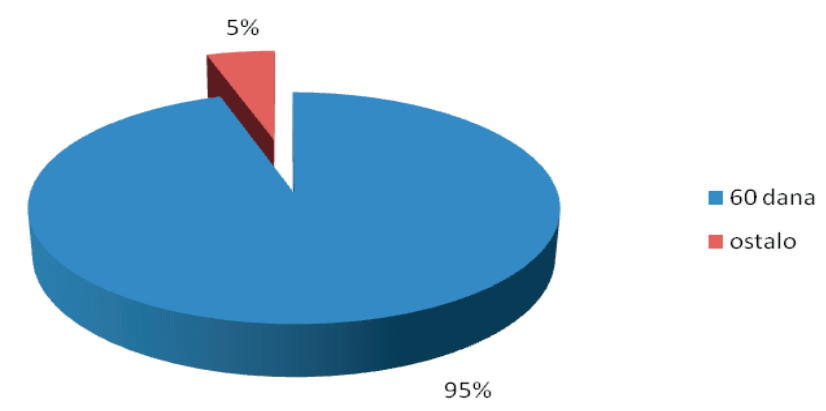

Image 2. The structure of the examines (legal entities) according to the Law on Accounting

The research results are explained in the following way: 60 days time period is not always seen as accounting ideal for the estimation of impaired account receivables. We cannot state that, if 60 days did not pass, the accounts receivable are not impaired for sure, and vice versa. The fact that almost all business entities in Serbia use that time period for estimation of impaired account receivables might be explained through the following arguments: a) it is about the deadline that is identical to the deadline stated in the Law on Corporate Income Tax and it is not necessary to calculate for the sake of structuring tax balance sheet; b) on the basis of computer software, the computer can extract those accounts receivable by itself (it is a technique of individual distinctive estimation), which accelerates the work in accounting and decreases the expenses of the estimation of impaired accounts receivables.

2. Are you familiar with the possibility to apply joint estimation of impaired account receivables, which have small value individually analyzed?

The fact that there was only $45 \%$ of examinees who responded positively, indicates dissatisfactory situation regarding the awareness of accountants about this matter.

3. Do you conduct separate research for each evaluation of impairment or you observe some research jointly?

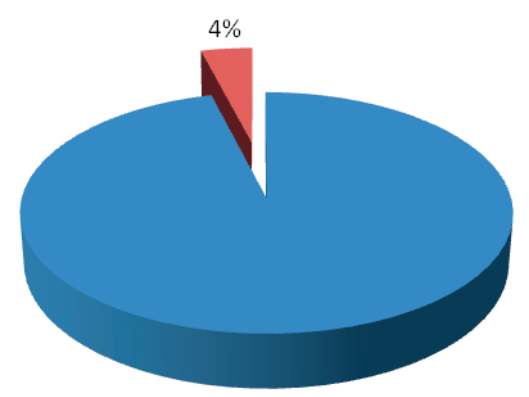

- pojedinačno ostalo

$96 \%$

Image 3. The estimation of impaired accounts receivable
The results of research indicate that $96 \%$ of examinees always conduct separate research for each receivable. It can be said that there is a small number of business entities that define the impairment of receivables in a correct manner, by treating a large number, individually small buyers, as one portfolio.

4. Do you analyze how much of the receivables in balance sheet are treated as impaired and collected in the specific period regularly each year?

On this question $65 \%$ of examinees responded that in their business entities those analyses are not conducted. According to these results, it can be stated that there is a relatively big number of participating business entities, which do not conduct the research of their procedure and the reality of estimation of impaired accounts receivable. This indicates the lack of awareness about the mistakes that are made through that estimation.

\section{SUMMARY}

The reality of estimation of impairment of accounts receivable depends on taking into account all the facts that indicate possible impairment of accounts receivable (for instance, illiquidity of debtor, his disputation of responsibility, etc.). In the previous discussion, we stated that the applied technique of estimation of impaired accounts receivable can affect its reality indirectly. Finally, we should not neglect tax "encouragement" from Article 16. in Law on Corporate Income Tax. Only one condition is enough to recognize taxed expenses and that 60 days passed from the deadline for the charge of impairment.

According to this research of relevant accounting and tax standards, which are important for balance sheet of impaired account receivable, and according to the estimation of impaired accounts receivable in Serbia, it can be said that we have proven the following hypotheses:

H1 - accounting standards that are implemented in Serbia enable realistic estimation of impaired accounts receivable (that reality also depends on the circumstances in which business entities and their debtors do their job);

$\mathrm{H} 2$ - in order to estimate the impairment of accounts receivable, a considerable number of business entities implement given accounting standard incorrectly, and do not analyze passed balance sheets, so as to upgrade their estimations in the following periods of financial reporting.

H3 - tax standard have a partially negative effect on the reality of estimation of impaired accounts receivable, indirectly.

The content of this work and the research results should encourage business entities to adjust the technique of estimation of impaired accounts receivable to the structure of their receivables which will contribute to more qualitative financial reporting.

\section{REFERENCES}

Agencija za privredne registre Republike Srbije. (2015). Godišnji bilten finansijskih izveštaja 2014. Datum preuzimanja 05.11.2015. http://www.apr.gov.rs/Portals/0/GFI/Makrosaopstenja/2014/Godisnji\%20bilten\%20FI\%202014.pdf?ver=2015-10-30-142557-660 
IFRS. (2015). IAS 39 Financial Instruments: Recognition and Measurement. Datum preuzimanja 05.11.2015. http://www. ifrs.org/IFRSs/Pages/IFRS.aspx

IFRS. (2014). IFRS for SMEs. Datum preuzimanja 05.11.2015. http://www.ifrs.org/IFRS-for-SMEs/Pages/IFRS-for-SMEs. aspx

Službeni glasnik RS. (2013). Pravilnik o načinu priznavanja, vrednovanja, prezentacije i obelodanjivanja pozicija u pojedinačnim finansijskim izveštajima mikro i drugih pravnih lica. Službeni glasnik RS, br. 118/2013 i 95/2014.
Službeni glasnik RS. (2001). Zakon o porezu na dobit pravnih lica. Službeni glasnik RS br. 25/2001, 80/2002, 80/2002 (dr. zakon), 43/2003, 84/2004, 18/2010, 101/2011, 119/2012, 47/2013, 108/2013, 68/2014 (dr. zakon), 142/2014 i 91/2015;

Službeni glasnik RS. (2013). Zakon o računovodstvu. Službeni glasnik RS br. 62/2013

\section{UTICAJ OBEZVREĐENJA POTRAŽIVANJA NA REALNOST FINANSIJSKOG IZVEŠTAVANJA SA OSVRTOM NA PRAKSU U REPUBLICI SRBIJI}

\section{Apstrakt:}

Ovaj rad bavi se teorijskim i praktičnim aspektom obračunavanja obezvređenosti potraživanja na realnost finansijskog izveštavanja. Cilj rada jeste da se istraži praksa obračuna obezvređivanja potraživanja pravnim licima u Republici Srbiji radi utvrđivanja eventualnih propusta (nepravilnosti) koji utiču na kvalitet finansijskog izveštavanja.

Brojni privredni subjekti imaju veliki broj pojedinačnih malih kupaca. $\mathrm{Na}$ osnovu sprovedenog istraživanja konstatujemo da su malobrojna pravna lica koja obezvređenost potraživanja utvrđuju na ispravan način - tretiranjem velikog broja pojedinačnih kupaca kao jednog portfelja. U tom smislu, smatramo da će sadržaj rada i zaključci uticati na način na koji računovođe obračunavaju obezvređenost potraživanja.

\section{Ključne reči:}

potraživanja, obezvređenost, portfelj, finansijski izveštaji. 